\title{
所謂「世 紀 末」
}

本間 久 雄

「世紀末」といふ言葉は云ふすでもなく, “Fin de Siècle”の訳語である。一時は,「紀 季」「紀末」などいふ訳もあったが，いつとはなしに「世紀末」に落ちついたやうである。 欧州では十九世紀の後半の半頃から末にかけて一種の流行語となり，日本では明治三十年 代の中程からしきりに用みられ，四十年代の始めの自然主義 全盛時代には一種の流行語と なってるた。明治三十七年一月号の雑誌「中央公論」の社説に“世紀末”と題するものが あるが、この社説など，「世紀末」を当時の日本が，どんな風に解釈してるたかがよくわ かる。それによると，そこには「従来の習慣や道徳などに反抗した思想」といふ意味と， 「老大家の時代が去って，新人の時代来る」といふ意味とがあるといふ。 それはとにかく「世紀末」といふ言葉が，我が国に用められ始めたのは，オーストリア 系のドイッの病理学者マックス, ノルダウ（Max Nordau 1849 - 1923）の "随落論“ (Degeneration) といふ書物が読まれ出してからであるやうである。この書は，もと，18 93年（明治二十六年）に Entartung の原名でドイッで出版されて評判となり，二年後の 1895年 (明治二十八年) には英訳されて，上記の題名で，ひろく欧米の読書界に，伝播紹介 されたものであった。

ノルダウのこの書は, 一言で云ふと, 著者が, ヨーロッパの近代の思想, 傾向, 文芸の 一切を, 病理学者としての立場から, 人類の随落, 変質, 退歩等の諸特質を物語る資料と して取上げて，それらの一切を痛烈に非難したものである，イブセン，トルストイ、ニー チェからユイスマン, ワイルドに至るまで, すべてが, 著者の痛棒を喰ってるるのである。 無論, 文芸そのものの鑑賞, 理解といふ点では, イギリスのアーサア・シモンス (Arthur Symons 1865-1945）などが，いち早く反駁しているょうに，私たちも，容易に，著者の結 論に組することは出来ないのである。しかし，著者が科学者であるところから文芸以外， 
英 学 史 研 究 第 6 号

ひろく社会的現象の中から種々の資料を集めてみる点は，今日の吾々にも参考になるとこ ろがあり, 且つ, その社会的諸現象についての解釈にも耳を傾けなければならないところ の極めて多いことも亦争はれぬ事実である。それはとにかく，「世紀末」といふ言葉は， 当時の一種の流行語であることは，近代の小説などを一瞥してもよく，うなづき得ること である。オスカア・ワイルドの有名な「ドリアン・グレー」の中の第十五章の作中人物の ヘンリー卿とドリアン・グレーとがナーボローといふ貴夫人に招がれての席上での会話に 次のやうな一節などその一例である。

"Fin de siècle" murmered Lord Henry "Fin du Globe" answered his hostess (Lady Narborough). I wish it were "Fin du Globe," said Dorian, with a sigh. "Life is a great disappointment."

日本の小説にも，例へば夏目漱石の『三四郎』の中にも，三四郎の友人與次郎が，三四 郎の顔を批評して「どうも妙な顔だな。いかにも生活に疲れてなるような顔だ。世紀末の 顔だ」と云ふところがある。さてヘンリイ卿の云った “Fin de siècle”ドリアン・グレー が溜息をつきながら「人生は大きな失望だ」と云った時の“Fin du Globe”とは何であら らか。"三四郎”の中の「世紀末の顔」とは,どらいふ顔であららか。

おもふに「世紀末」とい子ことには らの解釈が必要である。そして，この二つには，夫々全く相反する，少なくも夫々非常に 相異った見解があるのである。

先づ, 第一の範用問題から云ふと, 「世紀末」一䓂葉そのものからいへば, いつの世 紀でも，その終末が，世紀末であるが，文学史上，少なくも，こ>では，十九世紀に限定 してなる—といふのは，十九世紀の末と云っても，年代的にどれだけの範囲を指してい るかといふことである。ノルダウは, 漠然とながら, 十九世紀の後半の後半, すなはち, 1870, 80年代を指して居るのに対して, イギリスのホルブルック・ジャックソン (Holbrook Jackson (1874-1948)はそれをその名著 “一千八百九十年代” (The Eighteen Nineteenth) において，十九世紀の終末の十年間すなはち 1890 年代に限定してるるのである。ジャック ソンのこの書は, 1913 年の刊であるから, ノルダウの著書より後れること二十年であり, 


\section{所謂「世 紀 末」}

従って，この二人が取扱った「世紀末」の範围は夫々全く異ってるるのである。そして， この範囲そのもの>相違は, やがて又, 当然に, 二人の取扱った第二の「世紀末」の意義 の解釈問題に，大きな相違をもたらすことつなるのである。

この「世紀末」の意義についての解粕の相違を一言にして云へば，ノルダウの方は，上 に挙げたドリアン・グレーの所謂「人生は大きな失望だ」といふやうな人生否定の見解で あるに対して, ジャックソンの方は, 人生を明るく, 強く, 生きょうとする人生肯定の思 想であり, 又, ノルダウののが, 人類の変質, 退歩なのに比してジャックンンのは人生の 再生，復活，なのであり，つまり，思想的には，全く相反した観方なのである。先づ，， ルダウの方から述べて見よう。

“Fin de siècle,” といふ言葉の流行する前には 'Fin de race’ といふ言葉が流行した。 ノルダウは，こ〉から書き起して “Fin de siècle”を大体，次のやうに述べてるる。前々 からフランスでは，その民族の大部分を占めているラティン民族が，年々減少してゆくの で，十九世紀の終りにはやがてラティン民族が滅亡して了ひはせぬかといふ一種の恐怖感 に撉はれること〉なった。それが ‘Fin de race の思想であり，同時に Fin de siècle’ の 思想である。そしてこの思想の情趣が，一種の絶望的虚脱感となったところに十九世紀世 紀末の一つの特色がある。人類滅亡の思想は，遡ってロオマ衰頽時代にもあるにはあっ た。しかし，その時には，絶望的虚脱感の代りにたとひ低級な刹那主義であったとは云へ 'wine, woman \& song’ といふやうな, 積極的な一種の情趣がないことはなかった。十 九世紀の 'fin de siècle' には, さういふ積極的な要素は，いさ〉かもなかった。そこには 又，例へばゲーテの Faust のやうな宇宙の真理を㨔まうとか，人生の謎を解からとかいふ やうな高遠な煩閆から来る 厭世的な情調なども，一切なかった。そこにあるものは，た ぐ，一瞬間づ〉，死の方へ喘ぎつ〉ある病人の苦しい溜息のやうな，どうにもならぬ絶望 的な且つ虚脱的な思想であり，情調であった。

ノルダウは, 更につぶける。

この時代の特質は，不可思議に混淆してるる。そこには熱病的不安と，鈍重な落胆と， 恐るべき予言と，卑屈な諦めとが，交り合ってるる。今にも，世界が滅尽し，亡失して了 ふかのやらな情感が浱ってるる。世紀末は惐悔 （confession）であると同時に苦情の訴 
英 学 史 研 究 第 6 号

へ (complaint) である。古代北方の信仰には「神々のたそがれ」(The Dusk of the Gods）といふ恐ろしい教義が含まれてるるが，十九世紀の 終末には「国民のたそがれ」 (The Dusk of the Nations) といふ茫然とした苦悩が涱ってなた。そしてこの「たそが れ」の中に, あらゆる太陽とあらゆる星とは, びんびんに光を失み，人類は，今日まで， さまざまの制度や文物や創造を成就しては来たが，それらは，すべて「死にゆく世界」の 中に滅絶しつつあるのである。

ノルダウは, 大体かやうに説いてるる。つまり, 'fin de siècle’ とは, かやうな世界滅 亡観を根底とした一種の宿命観的な厠世気分であり, 情趣であり, 感情なのである。そして ノルダウは，さういふ厭世的情趣気分を説明し 解説するために，ッルゲーネフの 長篇作 『貴族の家』や，イブセンの作『幽霊』などを引合に出してみる。ついでながら『貴族の 家』が 1859年の作，『幽霊』が1881年の作であるところを見ても，ノルダウが， ‘fin de siècle’を年代的にいかに広い範囲のものとしてみるから゙，らから゙はれるのである。

さて, 次に, ノルダウとは, 反対の立場に立ったジャックソンの所説とは, どういふも のであるか。

追記 以上は昨年九月三日, 仙台における大会で, 私が特別講演として試みた「世紀末」 の梗概である。そこでは, 時間の都合上, ジャックンンの方を割愛せざるを得なかったの であった。いづれは機を見て本稿の欠を補ふことにしたい。 